Social Quality 
Also by Laurent J. G. van der Maesen

THE SOCIAL QUALITY OF EUROPE (edited with Wolfgang Beck and Alan Walker) SOCIAL QUALITY: A Vision for Europe (edited with Wolfgang Beck, Fleur Thomése and Alan Walker)

Also by Alan Walker

EAST ASIAN WELFARE REGIMES IN TRANSITION (edited with Chack Kie Wong) SOCIAL POLICY IN AGEING SOCIETIES (edited with Gerhard Naegele) FIGHTING POVERTY, INEQUALITY AND INJUSTICE (edited with Adrian Sinfield and Carol Walker) 


\section{Social Quality}

\section{From Theory to Indicators}

Edited by

Laurent J. G. van der Maesen

Director of the European Foundation on Social Quality,

The Hague, The Netherlands

and

Alan Walker

Professor of Social Policy and Social Gerontology,

University of Sheffield, UK

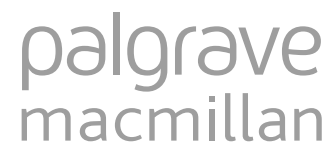


Selection and editorial matter $\odot$ Laurent J. G. van der Maesen and Alan Walker 2012 Individual chapters (c) their respective authors 2012

Softcover reprint of the hardcover 1st edition 2012 978-0-230-27852-3

All rights reserved. No reproduction, copy or transmission of this publication may be made without written permission.

No portion of this publication may be reproduced, copied or transmitted save with written permission or in accordance with the provisions of the Copyright, Designs and Patents Act 1988, or under the terms of any licence permitting limited copying issued by the Copyright Licensing Agency, Saffron House, 6-10 Kirby Street, London EC1N 8TS.

Any person who does any unauthorized act in relation to this publication may be liable to criminal prosecution and civil claims for damages.

The authors have asserted their rights to be identified as the authors of this work in accordance with the Copyright, Designs and Patents Act 1988.

First published 2012 by

PALGRAVE MACMILLAN

Palgrave Macmillan in the UK is an imprint of Macmillan Publishers Limited, registered in England, company number 785998, of Houndmills, Basingstoke, Hampshire RG21 6XS.

Palgrave Macmillan in the US is a division of St Martin's Press LLC, 175 Fifth Avenue, New York, NY 10010.

Palgrave Macmillan is the global academic imprint of the above companies and has companies and representatives throughout the world.

Palgrave ${ }^{\circledR}$ and Macmillan ${ }^{\circledR}$ are registered trademarks in the United States, the United Kingdom, Europe and other countries.

\section{ISBN 978-1-349-59187-9ＩSBN 978-0-230-36109-6 (eBook) DOI $10.1057 / 9780230361096$}

This book is printed on paper suitable for recycling and made from fully managed and sustained forest sources. Logging, pulping and manufacturing processes are expected to conform to the environmental regulations of the country of origin.

A catalogue record for this book is available from the British Library.

A catalog record for this book is available from the Library of Congress.

$\begin{array}{llllllllll}10 & 9 & 8 & 7 & 6 & 5 & 4 & 3 & 2 & 1\end{array}$

$\begin{array}{llllllllll}21 & 20 & 19 & 18 & 17 & 16 & 15 & 14 & 13 & 12\end{array}$ 
For Wolf and in memory of Annelies 


\section{Contents}

List of Tables ix

List of Figures $\quad \mathrm{x}$

Preface and Acknowledgements $\quad \mathrm{xi}$

List of Contributors xiii

1 Introduction 1

Laurent J. G. van der Maesen and Alan Walker

2 European and Global Challenges 19

Laurent J. G. van der Maesen and Alan Walker

3 Theoretical Foundations 44

Wolfgang Beck, Laurent J. G. van der Maesen and Alan Walker

4 Conceptual Location of Social Quality 70

Peter Herrmann, Laurent J. G. van der Maesen and Alan Walker

5 Social Quality Indicators

Peter Herrmann, Laurent J. G. van der Maesen and Alan Walker

6 Socio-Economic Security

Dave Gordon

7 Social Cohesion

Yitzhak Berman and David Phillips

8 Social Inclusion 173

Alan Walker and Carol Walker

9 Social Empowerment 198

Peter Herrmann

10 The Functions of Social Quality Indicators 224

Laurent J. G. van der Maesen 
viii Contents

11 Conclusion: Social Quality and Sustainability

Laurent J. G. van der Maesen and Alan Walker

References

275

Index 


\section{Tables}

3.1 The social quality architecture 66

6.1 Percentage of households receiving social benefits in EU countries in 1996

6.2 Redistribution of income in EU countries in $1998 \quad 126$

6.3 Redistribution of lifetime income in four countries 127

6.4 Location of food riots resulting in significant violence during 2007/2008 129

6.5 European indicators of socio-economic security 142

$\begin{array}{ll}7.1 & \text { Indicators of social cohesion } \\ 8.170\end{array}$

8.1 Indicators of social inclusion 196

$\begin{array}{lll}9.1 & \text { Power matrix } & 201\end{array}$

9.2 Indicators of social empowerment 217 


\section{Figures}

3.1 The constitution of the social 48

3.2 The interplay between two basic tensions 51

3.3 The quadrangle of the constitutional factors 57

3.4 The quadrangle of the conditional factors 61

4.1 The interaction between the second and third

5.1 The domains of the conditional factors 103

5.2 The tripartite composition of the conditional factors 109

6.1 OECD analysis of income poverty rates in the 1990s $\begin{array}{ll}\text { before and after transfers } & 125\end{array}$

6.2 The effects of the global economic crisis 131

6.3 The scale of the financial rescue in the USA and the UK 131

6.4 Average labour share of national income in OECD countries 133

6.5 Percentage of non-agricultural workforce at the time of the introduction of the second social insurance law $\quad 140$

8.1 Social cohesion and social inclusion 177

10.1 The six worlds of the urban space 246

11.1 Integration of the four dimensions of sustainability 253 


\section{Preface and Acknowledgements}

This is the third book produced by the European Foundation on Social Quality (EFSQ) and includes contributions from a number of researchers who have worked on the topic of social quality over the past decade. The foundations for this book were laid primarily by the European Network on Indicators of Social Quality (ENIQ), funded by the European Union's Fifth Framework Programme for Research and Technological Development, which gave considerable impetus to social quality thinking: theoretically, empirically and in policy terms. We are grateful for this important work. The authors of the national reports prepared by ENIQ are acknowledged in this volume in the references (ENIQ a-p). All contributors to this book were members of ENIQ. Inputs from the European Network on Employment and Social Quality, funded by the European Commission's Employment Directorate, were important and are also listed in the references (ENEQ a-h). Finally, this book has been inspired by the investigations into and applications of social quality in the Asia-Pacific region which began in the mid-2000s and which were led initially by Tetsuo Ogawa. Since 2010 this work has been organised efficiently by the Asian Consortium for Social Quality. Our thanks go to all our colleagues in the Asian Consortium and, especially, to Ka Lin for his tireless efforts on behalf of the social quality project.

This book would not have been completed without the support of the European Foundation's skeleton staff, especially Fleur Thomése, Christina Mercken, Joyce Hamilton, Margo Keizer, Robert Duiveman and Helma Verkleij. Also important were those who launched the European Journal of Social Quality, especially François Nectoux and colleagues at Kingston University, UK and Berghahn Books.

This book and the social quality project began with a European focus that reflected our strong belief in the necessity of European integration as the basis for responding to and preventing the worst excesses of the huge global transformations taking place. This integration requires a new societal theory to facilitate progress, address discrimination and exploitation, and promote social justice, solidarity, the equal value of all the human beings and human dignity. As a result of the Asia-Pacific collaboration we are also convinced that a key function of this new theory must be to further sustainability. Social quality cannot be a purely European manifestation; it must have relevance for all continents. 
Thus one important test of the usefulness and relevance of this concept is its capacity to facilitate comparative research. The current collaboration with the International Institute of Social Studies (ISS) in The Hague was a logical step and, since 2007, the ISS has housed the office of the EFSQ. This has stimulated many fruitful exchanges concerning human security and sustainability, and we are grateful to ISS colleagues for their collaboration, especially Rachel Kurian, Thandam Truong and Des Gasper.

The Board of the EFSQ also made essential contributions to this book by helping the Foundation to survive, on a series of shoestring budgets, and by leading the application of the social quality concept to frontline policy and practice in The Hague. Our special thanks go to Harry Nijhuis, Jaap Westbroek, Jan Winkelhuijzen, Teun Jaspers and Kees Knipscheer.

We have also received excellent technical assistance from the University of Sheffield over the years, from Olga Swales, Sarah Howson, Charlotte Jones, Karen Tsui, Marg Walker and Julia Tsai, for which we are grateful. Finally, our thanks go to our original collaborator on the social quality concept, Wolfgang Beck, who has remained a close friend and source of support and continued inspiration. 


\section{Contributors}

Wolfgang Beck is Advisor to the European Foundation on Social Quality, The Hague.

Yitzhak Berman was Research Associate at the European Centre in Vienna and is now retired.

Dave Gordon is Professor of Social Policy at the University of Bristol, UK.

Peter Herrmann is Lecturer in the School of Applied Studies, University College Cork, Ireland.

David Phillips, previously Reader in Social Policy, is Honorary Research Associate in the Department of Sociological Studies, University of Sheffield, UK.

Laurent J. G. van der Maesen is Director of the European Foundation on Social Quality, The Hague.

Alan Walker is Professor of Social Policy and Social Gerontology, University of Sheffield.

Carol Walker is Professor of Social Policy at the University of Lincoln, UK. 